\title{
SYNTHESIS AND CHARACTERIZATION OF INORGANIC SORBENTS AND THEIR APPLICATION TO SORPTION OF RADIONUCLIDES
}

\author{
G. Lujanienė ${ }^{\mathrm{a}}$, S. Meleshevych ${ }^{\mathrm{b}}$, V. Kanibolotskyy ${ }^{\mathrm{b}}, \mathrm{K}_{\text {. Mažeika }}{ }^{\mathrm{a}}$, V. Strelko ${ }^{\mathrm{b}}$, \\ V. Remeikis ${ }^{a}$, V. Kalenchuk ${ }^{b}$, and J. Šapolaite ${ }^{\mathrm{a}}$ \\ a Institute of Physics, Savanoriu 231, LT-02300 Vilnius, Lithuania \\ E-mail: lujaniene@ar.fi.lt \\ ${ }^{\mathrm{b}}$ Institute for Sorption and Problems of Endoecology, Generala Naumova 13, UA-03164 Kiev, Ukraine
}

Received 20 October 2007; accepted 22 February 2008

\begin{abstract}
Titanium silicates and iron oxides were synthesized. Their structural characteristics and sorption ability towards a number of radionuclides were studied using X-ray, Mössbauer, gamma, and alpha spectroscopy as well as the laboratory batch method. $\mathrm{X}$-ray studies of synthesized titanium silicates revealed their amorphous structure. Mössbauer spectrometry showed typical spectra of nanocrystalline goethite, hematite, magnetite, and the mixture of hematite and magnetite. Approximate size of nanocrystalline minerals was determined and it was in the range from about 14 to $30 \mathrm{~nm}$. Distribution coefficient $\left(K_{\mathrm{d}}\right)$ values obtained using the laboratory batch method ranged from 390 to $163000 \mathrm{ml} / \mathrm{g}$ for Sr, from 6 to $40470 \mathrm{ml} / \mathrm{g}$ for Cs, from 220 to $257000 \mathrm{ml} / \mathrm{g}$ for Pu, and from 50 to $16260 \mathrm{ml} / \mathrm{g}$ for Am.
\end{abstract}

Keywords: titanium silicates, iron oxides, sorption $\mathrm{Cs}, \mathrm{Sr}, \mathrm{Pu}, \mathrm{Am}$, distribution coefficient

PACS: $28.41 . \mathrm{Kw}$, 82.33.-z, 82.80.Ej, 82.80.Ip

\section{Introduction}

Nowadays numerous studies have been performed in order to identify new waste forms and disposal strategies because of large quantity of high activity radioactive waste which requires treatment prior to final disposal or storage. The application of inorganic sorbents such as ferrites and crystalline silicotitanates is one of the alternative technologies which can reduce the costs associated with waste disposal and minimize the contamination risk of the environment during processing and disposal of the radioactive waste. This issue is an especially hot topic nowadays in Lithuania because of the decommissioning of the Ignalina Nuclear Power Plant. The necessity of a highly efficient treatment stimulated studies in this field. The application of selective inorganic materials for the removal of harmful radionuclides from the bulk waste solution can be one of the possible solutions, because they are distinguished for high efficiency, ionizing radiation resistance, their thermal stability, and compatibility with the final waste forms.

The application of such a technique will result in considerable reductions in the volumes of waste that require solidification prior to final disposal, as well as in lower radioactive discharges from storage containers into the environment. New types of sorbents such as crystalline silicotitanates, tunnel type titanium silicates, transition metal hexacyanoferrates, etc., having high selectivity for various radionuclides, have recently been developed [1]. Crystalline silicotitanates have high selectivity for $\mathrm{Cs}^{+}$in solutions with high $\mathrm{Na}^{+}$concentrations, they are selective for $\mathrm{Sr}^{2+}$ and have low affinity for actinides. Substitution of $\mathrm{Nb}$ for $\mathrm{Ti}$ in the framework modified the selectivity towards $\mathrm{Cs}^{+}$and $\mathrm{Sr}^{2+}$. The $\mathrm{Nb}$ substitution increases sorption capacity towards $\mathrm{Cs}^{+}$ions and decreases $\mathrm{Sr}^{2+}$ selectivity. This effect is attributed to higher coordination number, an increase in the unit cell volume and change in water $/ \mathrm{Na}^{+}$population [2]. Among challenging materials are sodium titanate $\left(\mathrm{NaTi}_{2} \mathrm{O}_{5} \mathrm{H}\right)$, titanium silicates with pharmocosiderite structure, sodium nonatitanate $\left(\mathrm{Na}_{4} \mathrm{Ti}_{9} \mathrm{O}_{20} \cdot x \mathrm{H}_{2} \mathrm{O}\right)$, and heteropolymetalates $\left(\mathrm{M}_{12}\left[\mathrm{Ti}_{2} \mathrm{O}_{2}\right]\left[\mathrm{SiNb}_{12} \mathrm{O}_{40}\right] \cdot 16 \mathrm{H}_{2} \mathrm{O}, \mathrm{M}=\mathrm{Na}, \mathrm{K}\right)$.

Titanium compounds, e. g. titanium silicates and titanium dioxide, which is also known to be an excellent sorbent for a number of radionuclides and possesses catalytic activity, are excellent oxidizing agents [3]. This ability can be applied to the oxidative destruction in waste management. For instance, the combined treat- 
ment of spent decontamination solutions in the presence of titanium compounds could provide effective destruction of the complexing agents with release of radionuclides in a form suitable for sorption by the catalyst/ sorbent [4].

Ferrites and a variety of iron-containing minerals such as akaganeite, feroxyhyte, ferrihydrite, goethite, hematite, lepidocrocite, maghemite, and magnetite have been widely used as inorganic ion exchangers for the treatment of liquid wastes containing radioactive and hazardous metals $[5,6]$.

Ferrites possess the property of spontaneous magnetization, are crystalline materials soluble only in strong acid, and can be used for efficient separation by magnetic methods $[7,8]$. For instance, natural magnetite $\left(\mathrm{FeO} \cdot \mathrm{Fe}_{2} \mathrm{O}_{3}\right)$, due to its ferromagnetic property, can be used not only as an adsorbent for removing toxic metals from solution, but also in the high gradient magnetic separation process for attracting and retaining paramagnetic nanoparticles, thus removing them from solution [4].

The aim of this study was a comparative assessment of possible application of various synthetic and natural sorptive materials in liquid waste treatment technologies to remove long-lived radionuclides $\mathrm{Cs}, \mathrm{Sr}, \mathrm{Pu}$, and Am.

\section{Materials and methods}

\subsection{Synthesis of titanium silicates $\mathrm{Na}_{2} \mathrm{Ti}_{2} \mathrm{SiO}_{7} \cdot 2 \mathrm{H}_{2} \mathrm{O}$}

The method of titanium silicates preparation ( $\mathrm{Ti}: \mathrm{Si}=$ $1: 1)$ is based on precipitation of precursor from the $\mathrm{TiO}_{2}-\mathrm{SiO}_{2}-\mathrm{Me}_{2} \mathrm{O}$ alkaline solution followed by hydrothermal treatment (HT). The synthesis was performed under considerably soft conditions (under air pressure from $3-5$ to $0.3-0.4 \mathrm{mPa}$ and at $130-200{ }^{\circ} \mathrm{C}$ for 12-24 hours) in comparison with the well-known method by Poojary et al. [2]. Changes in the reaction conditions resulted in the product yield increase from 30 to $250-300 \mathrm{~g} / 1$ of initial reagents. Titanium silicates were synthesized using cheap and available Ukrainian raw materials - alkali silicate $\left(\mathrm{Na}_{2} \mathrm{SiO}_{3}\right)$, potassium/sodium methylsilicates $\mathrm{CH}_{3} \mathrm{Si}(\mathrm{OH})_{2} \mathrm{ONa}$ / $\mathrm{K}$, titanium tetrachloride $\left(\mathrm{TiCI}_{4}\right.$ ), and titanyl sulphate $\left(\mathrm{TiOSO}_{4}\right)$. Hydrogen peroxide was used as a complexing agent $[9,10]$.

\subsection{Synthesis of titanium silicates $\mathrm{Na}_{2} \mathrm{TiSiO}_{5} \cdot n \mathrm{H}_{2} \mathrm{O}$}

Synthesis of titanium silicates $(\mathrm{Ti}: \mathrm{Si}=1: 1)$ was performed using the sol-gel method developed at the In- stitute for Sorption and Problems of Endoecology, National Academy of Sciences of Ukraine. This method is based on the sol-gel technologies and local technical titanyl sulfate, and organic complexions as stockmaterials were used for the synthesis.

The initial reaction mixture contained solutions of technical $3.2 \mathrm{~mol} / 1 \mathrm{TiOSO}_{4}, 3.6 \mathrm{~mol} / 1 \mathrm{Na}_{2} \mathrm{SiO}_{3}$, and 4.5-5.0 mol/1 NaOH or KOH (for adjustment of $\mathrm{pH}$ ). Gel was prepared by fast and intensive mixing of stock solutions. After gel aging during one day, the hydrothermal treatment was performed in autoclaves under different conditions. Hydrothermically modified samples were thoroughly washed with water and then with ethanol for removing $\mathrm{Na}_{2} \mathrm{SO}_{4}$ and $\mathrm{K}_{2} \mathrm{SO}_{4}$ remaining in the system due to the specific sorption conditions. During the washing process, $\mathrm{pH}$ was controlled constantly. After that samples were dried at $120^{\circ} \mathrm{C}$ for 4 hours.

\subsection{Synthesis of iron oxides}

Iron oxides synthesis was performed using methods described in publications with some modifications [11-13]. Magnetite $\left(\mathrm{Fe}_{3} \mathrm{O}_{4}\right)$ was prepared by adding $1 \mathrm{M}$ ammonia solution $\left(\mathrm{NH}_{4} \mathrm{OH}\right)$ to $2 \mathrm{M} \mathrm{FeCl}_{2}$ and $1 \mathrm{M} \mathrm{FeCl}_{3}$ mixture (1:4). The temperature was kept at $90^{\circ} \mathrm{C}$. The synthesis was conducted under the $\mathrm{N}_{2}$ atmosphere. Particles were separated by magnet and dried under the $\mathrm{N}_{2}$ atmosphere.

Magnetite/hematite $\left(\mathrm{Fe}_{3} \mathrm{O}_{4}-\alpha-\mathrm{Fe}_{2} \mathrm{O}_{3}\right)$ composite was prepared by adding $2 \mathrm{M} \mathrm{FeCl}_{2}$ and $\mathrm{FeCl}_{3}$ (1:2) to $1 \mathrm{M}$ ammonia solution $\left(\mathrm{NH}_{4} \mathrm{OH}\right)$, with vigorous stirring for 40 min under the $\mathrm{N}_{2}$ atmosphere and at $50^{\circ} \mathrm{C}$ temperature. Particles were separated by centrifugation and dried for 90 min under vacuum.

Goethite $(\alpha-\mathrm{FeOOH})$ mineral was prepared by adding $5 \mathrm{M} \mathrm{NaOH}$ solution to $0.1 \mathrm{M} \mathrm{Fe}\left(\mathrm{NO}_{3}\right)_{3}$ solution until $\mathrm{pH}$ was 12 . The solution was stirred during 2 days at $60{ }^{\circ} \mathrm{C}$ temperature. The precipitate was washed and dialyzed in deionised water until the conductivity was stable at $10 \mu \mathrm{Scm}^{-1}$. Particles were separated and dried frozen.

Synthesis of hematite $\left(\alpha-\mathrm{Fe}_{2} \mathrm{O}_{3}\right)$ was conducted under the $\mathrm{N}_{2}$ atmosphere by mixing $0.5 \mathrm{M} \mathrm{FeCl}_{2}$ solution with $2.1 \mathrm{M} \mathrm{NaHCO}_{3}$ solution, well stirring until precipitate changed its colour to dark green. Then oxygen was introduced and the precipitate was washed until washings showed the presence of $\mathrm{Cl}$ ions. Suspension of hematite particles was separated from solution by cen- 
Table 1. Structural and sorptive characteristics of titanium silicate samples synthesized using $\mathrm{H}_{2} \mathrm{O}_{2}$.

\begin{tabular}{|c|c|c|c|c|c|c|c|}
\hline \multicolumn{2}{|c|}{$\mathrm{Ti}: \mathrm{Si}=2: 1$} & \multicolumn{2}{|c|}{ HT } & \multirow{2}{*}{$\begin{array}{c}\mathrm{pH} \text { of } \\
\text { washings }\end{array}$} & \multicolumn{2}{|c|}{$V_{\mathrm{s}}, \mathrm{cm}^{3} / \mathrm{g}$} & \multirow{2}{*}{$\begin{array}{c}S_{\text {spec. }}, \\
\mathrm{m}^{2} / \mathrm{g} \text { by argon }\end{array}$} \\
\hline Sorbent & Form & $t,{ }^{\circ} \mathrm{C}$ & $\tau$, hours & & $\mathrm{H}_{2} \mathrm{O}$ & $\mathrm{C}_{6} \mathrm{H}_{6}$ & \\
\hline 17 & $\mathrm{SO}_{4}$ & 150 & 24 & 9.00 & 0.18 & 0.34 & 228 \\
\hline 20 & $\mathrm{Cl}$ & 150 & 24 & 9.26 & 0.10 & 0.13 & 52 \\
\hline 30 & $\mathrm{SO}_{4}$ & 150 & 24 & 7.39 & 0.38 & 0.39 & 177 \\
\hline 32 & $\mathrm{SO}_{4}$ & 200 & 24 & 7.80 & 0.22 & 0.18 & 104 \\
\hline 55 & $\mathrm{Cl}$ & 150 & 24 & 9.60 & 0.22 & 0.21 & 64 \\
\hline $57+58$ & $\mathrm{Cl}$ & $150^{*}$ & 24 & $8.20^{*}$ & $0.22^{*}$ & $0.22^{*}$ & 62 \\
\hline 59 & $\mathrm{Cl}$ & 150 & 24 & 8.13 & 0.37 & 0.37 & 159 \\
\hline
\end{tabular}

* average values, $V_{\mathrm{s}}$ is sorption volume of pores by water $\left(\mathrm{H}_{2} \mathrm{O}\right)$, by benzene $\left(\mathrm{C}_{6} \mathrm{H}_{6}\right)$.

Table 2. Parameters of porous structure of titanium silicate synthesized using the sol-gel method.

\begin{tabular}{|c|c|c|c|c|c|c|c|c|c|c|}
\hline \multirow{2}{*}{$\frac{\mathrm{Ti}: \mathrm{Si}=1: 1^{*}}{\text { Sorbent }}$} & \multicolumn{2}{|c|}{ HT } & \multicolumn{2}{|c|}{ Washing } & \multirow[b]{2}{*}{$\mathrm{pH}$} & \multicolumn{2}{|c|}{ Calcination } & \multicolumn{2}{|c|}{$V_{\mathrm{s}}, \mathrm{cm}^{3} / \mathrm{g}$} & \multirow{2}{*}{$\begin{array}{c}S_{\text {spec. }}, \\
\mathrm{m}^{2} / \mathrm{g} \text { by } \operatorname{argon}\end{array}$} \\
\hline & $t,{ }^{\circ} \mathrm{C}$ & $\tau$, hours & $\mathrm{H}_{2} \mathrm{O}$ & Ethanol & & $t,{ }^{\circ} \mathrm{C}$ & $\tau$, hours & $\mathrm{H}_{2} \mathrm{O}$ & $\mathrm{C}_{6} \mathrm{H}_{6}$ & \\
\hline $40^{* *}$ & 200 & 6 & + & - & 11.5 & - & - & 0.21 & 0.16 & 237 \\
\hline $82-1$ & 150 & 6 & + & + & 9.2 & - & - & 0.47 & 0.68 & 726 \\
\hline $82^{\prime}-1$ & 150 & 6 & + & - & 9.7 & - & - & 0.18 & 1.10 & 64 \\
\hline $82-3$ & 150 & 6 & + & + & 9.9 & 400 & 10 & - & - & 145 \\
\hline $84-3$ & 150 & 6 & + & + & 9.9 & 400 & 2 & 0.19 & 0.46 & 191 \\
\hline $84-4$ & 150 & 6 & + & + & 9.9 & 400 & 10 & - & - & 189 \\
\hline $86-1$ & 150 & 6 & + & + & 10.4 & - & - & 0.23 & 0.71 & 251 \\
\hline $86-4$ & 150 & 6 & + & + & 10.4 & 400 & 10 & - & - & 189 \\
\hline
\end{tabular}

${ }^{*}$ in all feedstock solutions anion was present, ${ }^{* *}$ in $\mathrm{Na}$ form. All other samples are of $\mathrm{Na}, \mathrm{K}$ form.

trifugation, dried for several days at $90{ }^{\circ} \mathrm{C}$ and then aged for 5 hours at $500^{\circ} \mathrm{C}$.

\subsection{Physical and chemical analysis of prepared samples}

The BET surface area of TiSi sorbents was measured by the chromatografic method of argon thermal desorption [14].

The pore volume $V_{\mathrm{s}}$ of titanium-containing materials was determined using a standard technique - the desiccator method (sorption of benzene and water vapours) [14].

The X-ray diffraction studies of the prepared TiSi sorbents were conducted with an automated diffractometer (DRON-4-07) using Ni-filtered $\mathrm{Cu} K_{\alpha}$ radiation.

Synthesized iron oxides were characterized using Mössbauer spectroscopy. The samples were prepared using $\approx 50 \mathrm{mg}$ of synthesized material and mixing it with a small amount of $\mathrm{MgO}$ powder. Then the material was placed into a special holder and used for measurements. The thickness of samples was $\approx 17 \mathrm{mg} / \mathrm{cm}^{2}$ of studied material.

The Mössbauer spectra of the samples were recorded using the Mössbauer spectrometer operating in transmission geometry in a constant acceleration mode. The source of ${ }^{57} \mathrm{Co}$ in $\mathrm{Rh}$ matrix was used. For the description of Mössbauer spectra, separate subspectra (doublets and sextets) and hyperfine field $B$ distributions were applied.

Synthesized sorbents, both titanium silicates and iron oxides, as well as natural clay minerals (6 and 7) with $14 \%$ of montmorillonite were used in sorption experiments. The laboratory batch method was applied to determine the distribution coefficient $\left(K_{\mathrm{d}}\right)$ values of $\mathrm{Cs}, \mathrm{Sr}, \mathrm{Pu}$, and $\mathrm{Am}$ radionuclides.

${ }^{137} \mathrm{Cs}$ activities were measured with an intrinsic germanium detector (resolution $1.9 \mathrm{keV} / 1.33 \mathrm{MeV}$ and the relative efficiency of 42\%). Pu (IV) was used in the sorption experiment. Details of experiments are described in the previous publications $[15,16]$. Solids were separated from liquid by centrifugation for 20 minutes at $10000 \mathrm{~g}$. Plutonium and americium were determined after radiochemical separation using the UTEVA and TRU resins (Eichrom Industries) and precipitation with $\mathrm{NdF}_{3}$, then activities of $\mathrm{Pu}$ and Am were measured by alpha spectrometry. ${ }^{242} \mathrm{Pu}$ and ${ }^{243} \mathrm{Am}$ were used as tracers in the separation procedure. $\mathrm{Sr}$ was measured using atomic absorption spectrometry. $K_{\mathrm{d}}$ values for sorption of $\mathrm{Cs}, \mathrm{Sr}, \mathrm{Am}$, and $\mathrm{Pu}$ were determined from three replicates. 
Table 3. Description of Mössbauer spectra presented in Fig. 1.

\begin{tabular}{clccccc}
\hline Sample & \multicolumn{1}{c}{ Constituent } & $S, \%$ & $B, \mathrm{~T}$ & $\delta, \mathrm{mm} / \mathrm{s}$ & $\Delta, \mathrm{mm} / \mathrm{s}$ & $D, \mathrm{~nm}$ \\
\hline (a) & Antiferromagnetic goethite & 79 & $20-38$ & 0.37 & -0.27 & $\approx 20-30$ \\
& Paramagnetic goethite & 21 & 0 & 0.34 & 0.59 & \\
\hline (b) & Magnetite subspectrum A & 65 & $0-49.3$ & 0.29 & - & $\approx 14$ \\
& Magnetite subspectrum B & 35 & $0-46.0$ & 0.67 & - & \\
\hline (c) & Hematite & 58 & 51.9 & 0.38 & -0.2 & \\
& Magnetite subspectrum A & 22 & 48.5 & 0.31 & - & $\geq 30$ \\
& Magnetite subspectrum B & 20 & 44.7 & 0.54 & - & \\
\hline (d) & Hematite 1 subspectrum & 82 & 51.8 & 0.38 & -0.2 & \\
& Hematite 2 subspectrum & 8 & 50.8 & 0.38 & -0.2 & \\
\hline
\end{tabular}

$S$ is relative area of subspectrum attributed to the constituent of the sample, $B$ is hyperfine field, $\delta$ is isomer shift (relative to $\alpha-\mathrm{Fe}$ ), $\Delta$ is quadrupole splitting, $D$ is size of particles (crystallites). For hyperfine field distribution, the range of $B$ is indicated.

\section{Results and discussions}

\subsection{Identification and characterization of prepared samples}

Structural and sorptive characteristics of titanium silicates having the chemical formula $\mathrm{Na}_{2} \mathrm{Ti}_{2} \mathrm{SiO}_{7} \cdot 2 \mathrm{H}_{2} \mathrm{O}$ are shown in Table 1. It has been found that synthesis of titanium silicates using $\mathrm{TiOSO}_{4}$ (sorbents TiSi-17, TiSi-30) in comparison with titanium silicates, the synthesis of which was based on $\mathrm{TiCl}_{4}$ as feedstock (sorbents $\mathrm{TiSi}-20$, TiSi-32, TiSi-55, TiSi-(57+58), TiSi59), leads to the change in characteristics of the porous structure (sorptive volumes $V_{\mathrm{s}}$ measured by benzene and water are increased). It should be noted that an introduction of methyl group (synthesis was carried out using potassium methylsiliconate) to the titanium silicate structure (e. g. TiSi-17 sorbent prepared by a traditional technique using the hydrogen peroxide as a complexing agent) results in the formation of mesoporous products which are important for the sorption of big size ions.

Characteristics of porous structure of titanium silicates synthesized by the sol-gel method are presented in Table 2. An increase in the sorptive volume measured by benzene for the mixed $\mathrm{Na}$, K samples indicates their mesoporous nature. An additional water-ethanol treatment of mixed $\mathrm{Na}$, K titanium-containing xerogels by washing samples till $\mathrm{pH}$ of the solution reached 9.210.4 resulted in the significant enhancement of the surface area $\left(S_{\text {spec. }}\right)$ up to $251-726 \mathrm{~m}^{2} / \mathrm{g}$ (e.g. sorbent TiSi-82-1) in comparison with sample TiSi-40 (surface area of $237 \mathrm{~m}^{2} / \mathrm{g}$ ). The calcination of hydrothermally modified sorbents TiSi-82-3, TiSi-84-3, TiSi84-4, TiSi-86-4 revealed their high structural stability. However, it has been found that the stability tests and

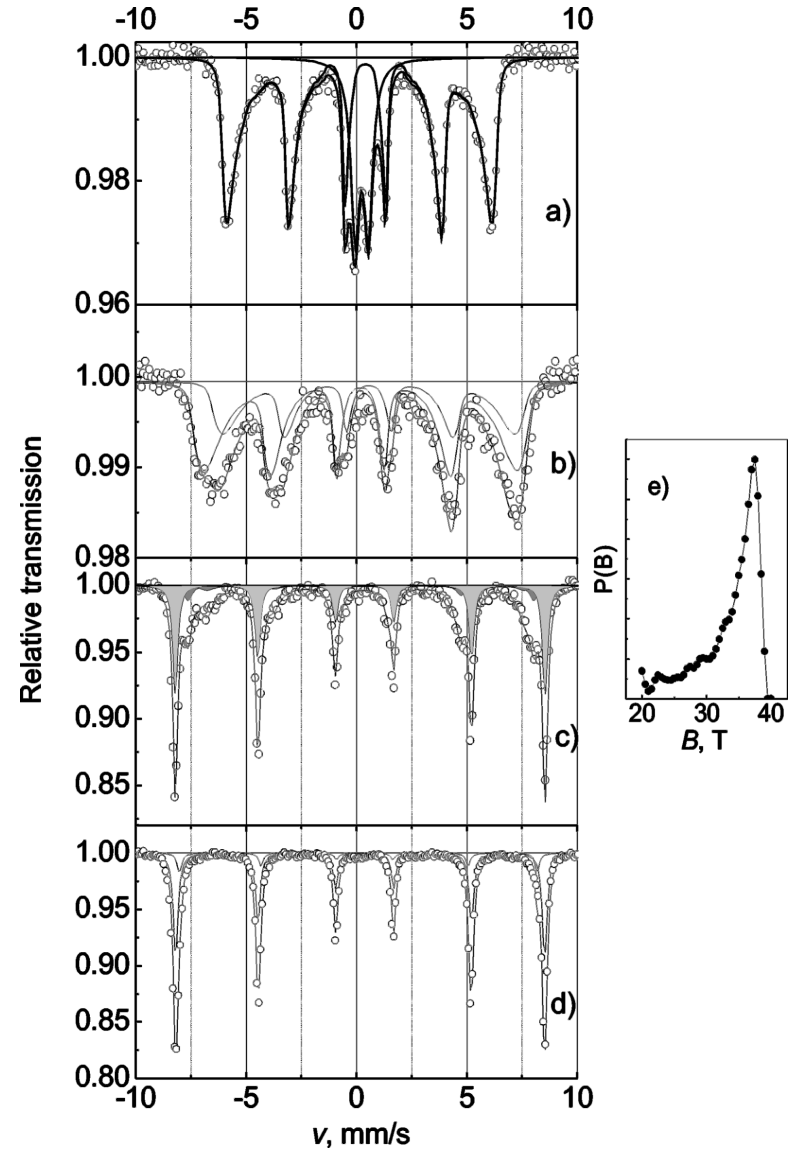

Fig. 1. Mössbauer spectra of (a) goethite $(\alpha-\mathrm{FeOOH})$, (b) nanocrystalline magnetite $\left(\mathrm{Fe}_{3} \mathrm{O}_{4}\right)$, (c) composite of hematite $\left(\alpha-\mathrm{Fe}_{2} \mathrm{O}_{3}\right)$ and magnetite $\left(\mathrm{Fe}_{3} \mathrm{O}_{4}\right)$, and (d) hematite $\left(\alpha-\mathrm{Fe}_{2} \mathrm{O}_{3}\right)$ samples. (e) Antiferromagnetic part of goethite $(\alpha-\mathrm{FeOOH})$ is described using hyperfine field distribution.

heating of samples up to $400{ }^{\circ} \mathrm{C}$ lead to some decrease in the surface area due to reconfiguration processes. Thus, changes in synthesis conditions, the chemical and hydrothermal treatment of titanium silicates can have an essential effect on their structural and sorption charac- 


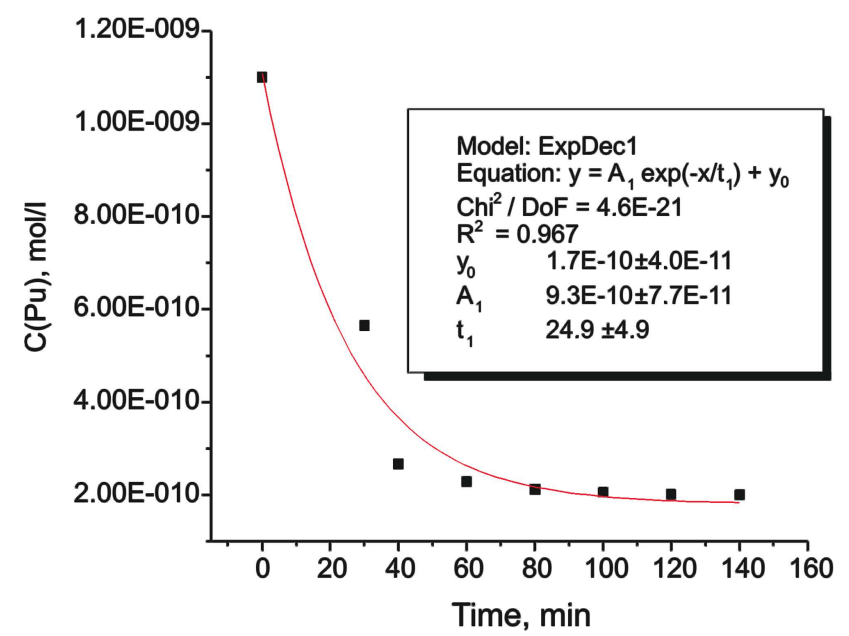

(a)

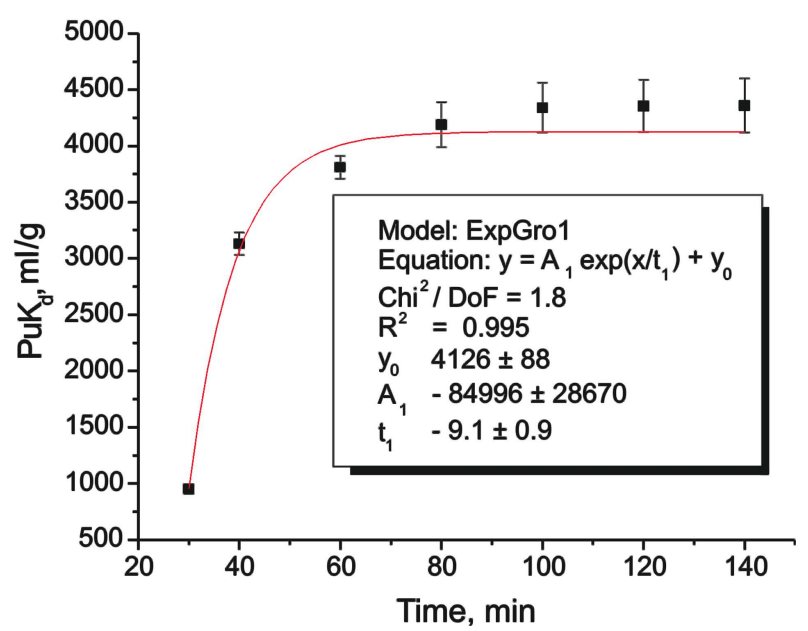

(b)

Fig. 2. Pu concentration in contact solution $\left(0.1 \mathrm{M} \mathrm{NaNO}_{3}\right)$ and $\mathrm{Pu} K_{\mathrm{d}}$ as a function of time (sorbent TiSi 55).

teristics. This is important when considering the possible practical application of the titanium silicates for the extraction of toxicants of different origin.

$\mathrm{X}$-ray investigations of titanium silicates synthesized by different techniques (precipitation and sol-gel methods) evidenced their amorphous structure.

The paramagnetic part of the Mössbauer spectrum of the goethite sample (Fig. 1(a)) is described using doublet (Table 3). For the description of antiferromagnetic part of the spectrum the distribution of hyperfine field $P(B)$ is used. In this case, the spectrum is expressed by the sum of sextets:

$$
f(v)=\sum_{i} P\left(B_{i}\right) f_{s}\left(B_{i}, v\right)
$$

where the hyperfine field $B$ of sextets $i$ and $i+1$ differs by $\Delta B=0.5 \mathrm{~T}$.

The broadening of Mössbauer lines (decrease in hyperfine fields compared with the static hyperfine field $B \approx 38 \mathrm{~T}$ specific to goethite) indicates the influence of the superparamagnetic relaxation of the magnetic moment due to small sizes of crystallites. The paramagnetic part (doublet) is a consequence of the superparamagnetism due to even smaller particles. The Mössbauer spectrum of the sample is typical of nanocrystalline goethite [17]. The determination of the sizes of particles of goethite on the basis of Mössbauer data may be only very approximate, especially because of the lack of knowledge of magnetic anisotropy values for this material. In this case, the average size of particles $D$ (Table 3) is evaluated by analogy with the results of Ref. [17].

Magnetite has two sublattices which are reflected in the Mössbauer spectrum and are described by separate subspectra. The subspectra of bulk magnetite are fitted to sextets with different static hyperfine fields $B$ and isomer shifts $\delta$. The Mössbauer spectrum of nanocrystalline magnetite is also described by two separate subspectra (Fig. 1(b)), but these are broadened, and therefore are expressed by hyperfine field distributions. The spectra lines become broadened because of small sizes of particles in nanocrystalline magnetite when the superparamagnetic relaxation of the magnetic moment occurs. The Mössbauer spectrum of nanocrystalline magnetite is fitted using two distributions of the hyperfine field and the relation between the particle size $D$ and the hyperfine field $B$. The size $D$ is considered to be distributed according to the lognormal law. A detailed description of the used method is presented in Ref. [18].

The Mössbauer spectrum of the third sample (Fig. 1(c)) is fitted using three sextets. The most intensive one which covers $\approx 58 \%$ of the spectrum area is caused by hematite. The second and third subspectra are characteristic of magnetite. Slightly smaller hyperfine fields for these subspectra compared with the static ones indicate the presence of small particles in the sample.

The Mössbauer spectrum of the fourth sample (Fig. 1(d)) is fitted using two sextets with parameters which are typical of hematite. The second sextet of a much smaller area compared with the first one is needed to improve the fitting quality. It has a slightly smaller value of the hyperfine field than that of the first one and also indicates the effect of superparamagnetism of small particles. 


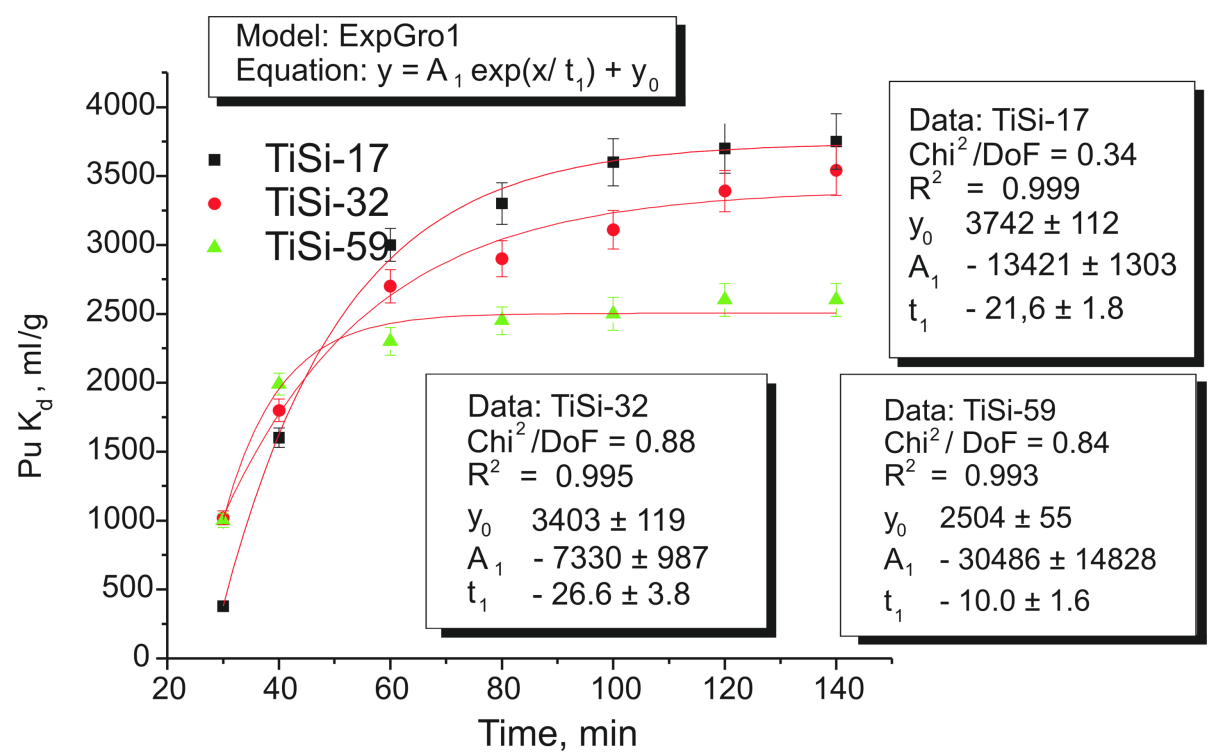

Fig. 3. $\mathrm{Pu} K_{\mathrm{d}} \mathrm{S}$ as functions of time.

Table 4. $\mathrm{Sr}, \mathrm{Cs}, \mathrm{Pu}$, and $\mathrm{Am} K_{\mathrm{d}} \mathrm{s}$ for titanium silicates and minerals used in this study.

\begin{tabular}{|c|c|c|c|c|}
\hline Sorbent, No. & ${ }^{*} \mathrm{Sr} K_{\mathrm{d}}, \mathrm{ml} / \mathrm{g}$ & ${ }^{* *} \mathrm{Cs} K_{\mathrm{d}}, \mathrm{ml} / \mathrm{g}$ & ${ }^{* *} \mathrm{Pu} K_{\mathrm{d}}, \mathrm{ml} / \mathrm{g}$ & ${ }^{* *} \mathrm{Am} K_{\mathrm{d}}, \mathrm{ml} / \mathrm{g}$ \\
\hline TiSi 17 & $19500 \pm 7200$ & $15860 \pm 550$ & $4590 \pm 110$ & \\
\hline TiSi 20 & $12000 \pm 4300$ & $24180 \pm 700$ & & \\
\hline TiSi 30 & $197000 \pm 7500$ & $12570 \pm 340$ & $2870 \pm 60$ & \\
\hline TiSi 32 & $220000 \pm 7300$ & $8750 \pm 230$ & $1240 \pm 30$ & $270 \pm 20$ \\
\hline TiSi 40(s) & $2630 \pm 150$ & $310 \pm 10$ & $1500 \pm 40$ & \\
\hline TiSi 55 & $163000 \pm 7500$ & $21160 \pm 520$ & $4030 \pm 100$ & \\
\hline TiSi $57+58$ & $17100 \pm 9800$ & $7270 \pm 140$ & $2730 \pm 70$ & $905 \pm 50$ \\
\hline TiSi 59 & $163000 \pm 7200$ & $40470 \pm 1100$ & $2590 \pm 60$ & \\
\hline TiSi 82-1 & $5580 \pm 230$ & $1460 \pm 30$ & $570 \pm 30$ & $2900 \pm 100$ \\
\hline TiSi 82’-1 & $1910 \pm 110$ & $470 \pm 15$ & $1550 \pm 70$ & \\
\hline TiSi 82-3 & $1800 \pm 100$ & $200 \pm 10$ & $2530 \pm 100$ & $3300 \pm 120$ \\
\hline TiSi 84-3 & $3020 \pm 130$ & $640 \pm 25$ & $3570 \pm 120$ & $5670 \pm 300$ \\
\hline TiSi 84-4 & $1960 \pm 90$ & $460 \pm 20$ & $400 \pm 20$ & $4050 \pm 200$ \\
\hline TiSi 86-1 & $2550 \pm 120$ & $1180 \pm 60$ & $290 \pm 10$ & \\
\hline TiSi 86-4 & $1830 \pm 90$ & $550 \pm 20$ & $2430 \pm 100$ & $1480 \pm 60$ \\
\hline PSiZr & $920 \pm 50$ & $144 \pm 20$ & $220 \pm 10$ & $110 \pm 10$ \\
\hline $\mathrm{Zr}_{3}\left(\mathrm{PO}_{4}\right)_{4}$ & $1210 \pm 70$ & $381 \pm 15$ & $1520 \pm 60$ & $1030 \pm 40$ \\
\hline $\mathrm{ZrO}_{2}$ & $1150 \pm 50$ & $6 \pm 0.5$ & $2640 \pm 110$ & \\
\hline TiP 1.0 & $3300 \pm 130$ & $1790 \pm 70$ & $2080 \pm 80$ & $1790 \pm 70$ \\
\hline TiP 1.5 & $2040 \pm 100$ & $1589 \pm 50$ & $2350 \pm 55$ & $470 \pm 20$ \\
\hline TiP 2.0 & $3100 \pm 170$ & $2100 \pm 60$ & $1960 \pm 60$ & $50 \pm 5$ \\
\hline $\mathrm{MgFe}(\mathrm{OH})_{x} \cdot n \mathrm{H}_{2} \mathrm{O}$ & $12250 \pm 700$ & $725 \pm 20$ & $4025 \pm 120$ & $7940 \pm 300$ \\
\hline Clay 6 & $290 \pm 10$ & $7860 \pm 100$ & $3570 \pm 100$ & $11160 \pm 560$ \\
\hline Clay 7 & $390 \pm 25$ & $7528 \pm 130$ & $2470 \pm 60$ & $6070 \pm 300$ \\
\hline Magnetite & $1150 \pm 50$ & $30 \pm 1$ & $1450 \pm 50$ & $11670 \pm 520$ \\
\hline
\end{tabular}

${ }^{*} \mathrm{Sr} K_{\mathrm{d}}$ values for natural groundwater; ${ }^{* *} \mathrm{Cs}, \mathrm{Pu}$, and $\mathrm{Am} K_{\mathrm{d}}$ values for $0.1 \mathrm{M} \mathrm{NaNO}_{3}$ solution. 
Table 5. Pu and Am $K_{\mathrm{d}} \mathrm{S}$ for synthetic iron oxides and natural groundwater.

\begin{tabular}{ccc}
\hline Sorbent & $\mathrm{Pu} K_{\mathrm{d}}, \mathrm{ml} / \mathrm{g}$ & $\mathrm{Am} K_{\mathrm{d}}, \mathrm{ml} / \mathrm{g}$ \\
\hline Magnetite & $9000 \pm 400$ & $6760 \pm 300$ \\
Magnetite/hematite & $61500 \pm 3000$ & $4750 \pm 200$ \\
Goethite & $15670 \pm 600$ & $14530 \pm 700$ \\
Hematite & $257620 \pm 10000$ & $16260 \pm 800$ \\
\hline
\end{tabular}

\subsection{Sorption of radionuclides}

Some studies were performed in order to determine the sorption ability of synthesized inorganic sorbents towards $\mathrm{Sr}, \mathrm{Cs}, \mathrm{Pu}$, and Am (Table 4).

Sorbent TiSi-17 showed the highest $\mathrm{Pu} K_{\mathrm{d}}$ value for $1 \mathrm{M} \mathrm{NaNO}_{3}$ solution which is usually used to model fuel pond water with $\mathrm{pH}$ of about 7 . The obtained highest $K_{\mathrm{d}}$ value can be explained by the methyl group introduction into the Ti silicate structure. As was mentioned above, sorbent $\mathrm{TiSi}-17$ was synthesized using the potassium methyl silicon and the hydrogen peroxide as complexon. Thus, the formation of sorbents with a mesoporous structure suitable for sorption of large size ions was expected. Preliminary data have suggested that $\mathrm{Am} K_{\mathrm{d}}$ values are quite close to the Pu ones. Studies of Am sorption are in progress.

Data on $\mathrm{Pu}$ sorption kinetics have indicated that rather short time is required to reach equilibrium (Figs. 2 and 3). Equilibrium was reached after about 2 hours of sorption. Data were fitted by the first order kinetic equation to obtain $\mathrm{Pu} K_{\mathrm{d}}$ equilibrium which ranged from 2500 to $4130 \mathrm{ml} / \mathrm{g}$ for studied sorbents TiSi-17, TiSi32, TiSi-55, and TiSi-59.

Preliminary data on Pu sorption to iron minerals are presented in Table 5. $K_{\mathrm{d}}$ values ranged from 4750 to $16260 \mathrm{ml} / \mathrm{g}$ and 9000 to $257620 \mathrm{ml} / \mathrm{g}$ for Am and $\mathrm{Pu}$, respectively, and the determined values were in a close range as determined for natural clay $[15,16]$. An increase in the $\mathrm{Pu} K_{\mathrm{d}}$ value by a factor of 6.8 was found for magnetite / hematite composite in comparison with that for pure magnetite. Thus, synthesized magnetite/hematite composites possess magnetic properties and better sorption ability towards Pu.

\section{Conclusions}

Synthesized inorganic sorbents are extremely chemically stable and have exclusive selectivity towards radiostrontium as well as radiocesium even in solutions with high $\mathrm{Na}^{+}, \mathrm{Ca}^{2+}$, and $\mathrm{Mg}^{2+}$ concentrations.

Data on $\mathrm{Pu}$ sorption kinetics have indicated that rather short time is required to reach equilibrium. Equilibrium was reached after about 2 hours of sorption.

The synthesized magnetite/hematite composite showed magnetic properties and better sorption ability towards $\mathrm{Pu}$ in comparison with the pure magnetite.

\section{Acknowledgements}

This study was supported by the Ukrainian Ministry of Education, the Ministry of Education and Science of the Republic of Lithuania and the Lithuanian State Science and Studies Foundation projects No. 580 and No. V-35/ 2007.

\section{References}

[1] A. Clearfield, Structure and ion exchange properties of tunnel type titanium silicates, Solid State Sci. 3, 103112 (2001).

[2] D.M. Poojary, A.I. Bortun, L.N. Bortun, and A. Clearfield, Sructural studies on the ion-exchanged phases of porous titanosilicate, $\mathrm{Na}_{2} \mathrm{Ti}_{2} \mathrm{SiO}_{7} 2 \mathrm{H}_{2} \mathrm{O}$, Inorg. Chem. 35, 6131-6139 (1996).

[3] A. Bhaumik, S. Samanta, and N.K. Mal, Highly active disordered extra large pore titanium silicate. Microporous Mesoporous Mater. 68, 29-35 (2004).

[4] Combined Methods for Liquid Radioactive Waste Treatment, IAEA-TECDOC-1336 (IAEA, Vienna, 2003).

[5] R.G. Dosch, N.E. Brown, H.P. Stephens, and R.G. Anthony, Treatment of liquid nuclear wastes with advanced forms of titanate ion exchangers, in: Proceedings of the International Symposium on Waste Management '93, Vol. 2 (Tucson, Arizona Board of Regents, Phoenix, AZ, 1993) p. 1751.

[6] Application of Ion Exchange Processes for the Treatment of Radioactive Waste and Management of Spent Ion Exchangers, IAEA Technical Reports Series No. 408 (IAEA, Vienna, 2002).

[7] J.D. Navratil, Pre-analysis separation and concentration of actinides in groundwater using a magnetic filtration/ sorption method I. Background and concept, J. Radioanal. Nucl. Chem. 248, 571-574 (2001).

[8] J.D. Navratil, Advances in treatment methods for uranium contaminated soil and water, Arch. Oncol. 9, 257-260 (2001).

[9] V. Kanibolotskyy, S. Meleshevych, V. Strelko, V. Kalenchuk, and N. Shenk, Process of preparation of titanosilicate ion-exchanger, Patent of Ukraine No. 76786A, IPC6 C01B 33 / 20; claimed 07.05.2004; published 15.09.2006; Bull. No. 9 [in Russian].

[10] S. Meleshevych, V. Kalenchuk, V. Kanibolotskyy, N. Shenk, V. Strelko, T. Psaryova, and O. Zakutevskyy, Process of preparation of titanosilicate ion-exchanger, 
Patent of Ukraine No. 76886A, IPC6 C01B 33/20; claimed 23.12.2004; published 15.09.2006; Bull. No. 9 [in Russian].

[11] U. Schwertmann and R.M. Cornell, Iron Oxides in the Laboratory (VCH Verlag, Weinheim, Germany, 1991).

[12] P. Raming, A.J.A. Winnubst, C.M. van Kats, and A.P. Philips, The synthesis and magnetic properties of nanosized hematite $\left(\alpha-\mathrm{Fe}_{2} \mathrm{O}_{3}\right)$ particles, J. Colloid Interface Sci. 249, 346-350 (2002).

[13] G. Lefevre, S. Noinville, and M. Fedoroff, Use of attenuated total reflection - infrared spectroscopy to in situ study adsorption of uranyl onto hematite, J. Colloid Interface Sci. 296, 608-613 (2006).

[14] N.V. Keltsev, The Essential Principles of Adsorption Engineering (Khimia, Moscow, 1984) [in Russian].
[15] G. Lujanienè, J. Šapolaitè, A. Amulevičius, K. Mažei$\mathrm{ka}$, and S. Motiejūnas, Retention of cesium, plutonium and americium by engineered and natural barriers, Czech J. Phys. 56, D103-D110 (2006).

[16] G. Lujanienè, S. Motiejūnas, and J. Šapolaite, Sorption of $\mathrm{Cs}, \mathrm{Pu}, \mathrm{Am}$ on clay minerals. J. Radioanal. Nucl. Chem. 274, 345-353 (2007).

[17] G.J. Long, D. Hautot, F. Grandjean, D. Vandormael, and H.P. Leighly, A Mössbauer spectral study of the hull steel and rusticles recovered from Titanic, Hyperfine Interactions 155, 1-13 (2004).

[18] K. Mažeika, J. Reklaitis, G. Lujanienè, D. Baltrūnas, and A. Baltušnikas, Modification of nanocrystalline magnetite by milling, Lithuanian J. Phys. 46, 451-457 (2006).

\title{
NEORGANINIŲ SORBENTU SINTEZĖ IR APIBŪDINIMAS BEI JŲ TAIKYMAS RADIOAKTYVIŲJŲ NUKLIDŲ SORBCIJAI
}

\author{
G. Lujaniené $^{\mathrm{a}}$, S. Meleshevych ${ }^{\mathrm{b}}$, V. Kanibolotskyy ${ }^{\mathrm{b}}, \mathrm{K}$ Mažeika $^{\mathrm{a}}$, V. Strelko ${ }^{\mathrm{b}}$, V. Remeikis ${ }^{\mathrm{a}}$, V. Kalenchuk ${ }^{\mathrm{b}}$, \\ J. Šapolaité ${ }^{\mathrm{a}}$ \\ ${ }^{a}$ Fizikos institutas, Vilnius, Lietuva \\ ${ }^{\mathrm{b}}$ Sorbcijos ir endoekologijos problemu institutas, Kijevas, Ukraina
}

\section{Santrauka}

Susintetinti titano silikatai ir geležies oksidai. Naudojant Rentgeno, Mesbauerio, gama ir alfa spektroskopiją bei laboratorinès sorbcijos metodu buvo tiriamos gautu neorganiniu sorbentų struktūrinès charakteristikos ir cezio, stroncio, plutonio ir americio sorbcijos geba. Rentgeno spektroskopijos metodu tiriant susintetintą titano silikatą, nustatyta jo amorfinè struktūra. Pritaikius Mesbauerio spektrometriją gauti būdingi nanokristalinio getito, hematito, magnetito bei hematito ir magnetito mišinio spektrai. Buvo įvertintas nanokristalinių mineralų dydis, kuris kito nuo 14 iki $30 \mathrm{~nm}$. Pa- siskirstymo koeficiento $\left(K_{\mathrm{d}}\right)$ vertès, gautos laboratorinès sorbcijos metodu, kito nuo 390 iki $163000 \mathrm{ml} / \mathrm{g} \mathrm{Sr}$, nuo 6 iki $40470 \mathrm{ml} / \mathrm{g} \mathrm{Cs}$, nuo 220 iki $257000 \mathrm{ml} / \mathrm{g}$ Pu ir nuo 50 iki $16260 \mathrm{ml} / \mathrm{g} \mathrm{Am}$.

Susintetinti neorganiniai sorbentai yra labai chemiškai stabilūs ir ypatingai atrankiai sorbuoja radiostronci bei radiocezi, net ir dideliu $\mathrm{Na}^{+}, \mathrm{Ca}^{2+}$ ir $\mathrm{Mg}^{2+}$ koncentraciju tirpaluose. Pu sorbcijos kinetikos eksperimentu metu pastebèta, kad reikia palyginti trumpo laiko pusiausvyrai pasiekti ( 2 val. nuo sorbcijos pradžios). Ištyrus susintetintą magnetito ir hematito mišini parodyta, kad šio mišinio $\mathrm{Pu}$ sorbcijos geba geresnè, nei gryno magnetito. 